\title{
Evaluation of physical and chemical characteristics of sixty peanut germplasm
}

\author{
ERLIANA GINTING ${ }^{\boldsymbol{\gamma}}$, NOVITA NUGRAHAENI \\ Indonesian Legumes and Tuber Crops Research Institute. Jl. Kendal Payak No. 66, Pakishaji, Malang 65162, East Java, Indonesia. \\ Tel./fax.+62-341-801468, `email: erlianaginting@yahoo.com
}

Manuscript received: 27 March 2020. Revision accepted: 29 May 2020.

\begin{abstract}
Ginting E, Nugrahaeni N. 2020. Evaluation of physical and chemical characteristics of sixty peanut germplasm. Biodiversitas 21: 2840-2847. Nutritional values of peanut, particularly protein and fat is essential in terms of predominant use of peanut for foods. The seed size is also important for end use of the products. This study aimed to evaluate the physical and chemical characteristics of sixty ILETRI's peanut germplasm was performed. The results showed that the major genotypes had rose seed coat colors with two seeds per pod and average dried pod yield of $3.09 \mathrm{t} / \mathrm{ha}$. Twenty-one genotypes belonged to large-seeded ( $\geq 55 \mathrm{~g} / 100 \mathrm{seeds})$ and thirty-six were medium (40-55 g). The ash contents slightly varied from $2.53 \%$ to $2.98 \%$ (dw). One genotype (MLGA 0444) contained high protein (> $30 \% \mathrm{dw})$, while high-fat contents (> $43 \% \mathrm{dw}$ ) were noted in all genotypes. Selected genotypes had favored combinations of seed size, protein, and fat contents with high pod yield. Based on the similarity of 100-seed weights, ash, protein, and fat contents, sixty genotypes were grouped into three clusters with the main differences in seed sizes. Nineteen genotypes in cluster II with large seed size, medium protein, and high-fat content characteristics, particularly are suitable for oil extraction breeding purposes.
\end{abstract}

Keywords: germplasm, nutrients, peanut, physical characters

\section{INTRODUCTION}

Peanut is a good source of protein, lipid, and unsaturated fatty acids as well as vitamins, minerals, dietary fibers, and bioactive components (Janila et al. 2013, Arya et al. 2016) that are beneficial for human health. In Indonesia, the utilization of peanut for foods constitute about $85 \%$ of the total annual production (605,449 tons) with a consumption level of $0.27 \mathrm{~kg} / \mathrm{capita} /$ year (Respati et al. 2014, Statistics Indonesia 2015). Peanut products, such as sauces for salads and satay, snacks (boiled, deep-fried, roasted, flour-coated), bakery fillers, peanut tempe or oncom, peanut butter, and edible oil are commonly consumed and available in the market (Ginting and Rahmianna 2015). Therefore, peanut with desirable physical and chemical characteristics tailored for food products is warranted.

In terms of using peanut for direct consumption, particularly as snacks and confectionery, the physical attributes, such as shape, size, and color are essential. In addition, the chemical attributes are also important as it would affect the sensory and nutritional value of the products. These characteristics include large seed size, high sucrose and protein contents, low glucose, and oil contents as well as high oleic acid/linoleic acid ratio (Bishi et al. 2013). Meanwhile, high oil content is desired for oil source purposes, which can be further processed into edible oil, margarine, shortening, chemical, and cosmetic products (Zulchi et al. 2016). Both large and small-seeded peanut is suitable for sauce and filler ingredients, however smallseeded is preferred for flour-coated peanut. Peanut with seed weight $>55 \mathrm{~g} / 100$-seed belongs to large-seeded, while it was medium for 40-55 g/100-seed and small for <40 $\mathrm{g} / 100$-seed (Trustinah 2009). The protein content of peanut normally varies from 20 to $40 \%$, while fat content is considerably higher, ranging from 40 to $50 \%$ (Sebei et al. 2013). Peanut oil contained no cholesterol and consists of $82 \%$ of unsaturated fatty acids, primarily oleic and linoleic acids, and to a lesser extent linolenic acid (Toomer 2018), giving a beneficial health issue in terms of lowering serum cholesterol levels (Bishi et al. 2013). Genotype/cultivar, growth/environmental conditions, location, and maturity may affect the physical and chemical characteristics of peanut that would ultimately dictate the quality of the products.

The availability of germplasm as genetic material resources is essential in terms of breeding suitable peanut cultivars for both food and industrial purposes. Indonesian Legumes and Tuber Crops Research Institute (ILETRI) has collected about 660 accessions since 1984 and currently identified the traits based on the established reference, namely IPGRI 1985 and UPOV 1985 (Trustinah 2009) in order to have a complete database and valuable information, particularly for the breeder. In addition to desired morphological and agronomical characters, such as high yield potential and resistance to biotic and abiotic elicitors, the quality traits and nutritional aspects of peanut germplasm for food uses also need to be identified. Such studies had been performed for selected peanut germplasm in India (Sarvamangala et al. 2011; Upadhyaya et al. 2012; Bishi et al. 2013), US (Dean et al. 2009), China (Wang et al. 2011; Hou et al. 2017), and Indonesia (Zulchi et al. 2016; Zulchi and Puad 2017). Therefore, this study aimed to evaluate the physical and chemical properties of sixty 
ILETRI's peanut germplasm collections with particular concern on seed size, ash, protein, and fat contents. Moderate heritability was noted previously for fat content of peanut, while it ranged from moderate to high for protein content (Noubissié et al. 2012; Jibrin 2016; Kabbia et al. 2017). Regarding the seed size, large-seeded peanut seemed to be dominant toward the small-seeded (Kabbia et al. 2017).

\section{MATERIALS AND METHODS}

The study was performed at the ILETRI's Laboratory of Food Chemistry in Malang, Indonesia. About 60 peanut accessions consisting of 19 Indonesian local varieties, 30 introduction varieties from ICRISAT, India, and 11 Indonesian breeding lines (Table 1) were taken randomly from the rest of 540 ILETRI's germplasm collection that has not been evaluated for their nutritional traits. They were grown at the onset of rainy season (April) in Jambegede Experimental Field, Malang, East Java and harvested three months after planting. The fertilizer applied was $300 \mathrm{~kg}$ of NPK compounds with a ratio of 15-15-15 and $36 \mathrm{~kg}$ of $\mathrm{P}_{2} \mathrm{O}_{5}$ per ha, respectively, followed by optimal soil tillage, drainage, weed, pest, and disease controls. Harvesting was done by pulling out the plant and the pods were manually separated, then sorted and dried until the moisture content is below 10\%. Physical analysis included visual observation for the color of seed coat (testa), number of seed per pod, and 100-seed weight. Meanwhile, chemical analysis was performed for moisture and ash contents using gravimetric methods (Indonesian National Council for Standardization 1992), fat content using direct extraction method/Soxhlet as referred to Indonesian National Council for Standarization (1992) and microKjeldahl method for protein content (AOAC 2016). Analysis was done in triplicate and data was presented as a means of triplicate analysis. Data were also statistically analyzed using ANOVA and those parameters that were significantly different $(P<0.05)$ would be further used for cluster analysis. Minitab 14 software was applied for frequency analysis of 60 peanut genotypes as well as cluster analysis using linkage centroid method.

As a supportive data, dried pod yield of each genotype was collected and categorized as high $(\mathrm{H})$, medium $(\mathrm{M})$, and low (L), respectively using a formula as follow: $\mathrm{H}=(>$ mean $+0,5 \mathrm{stdv}), \mathrm{M}=(>$ mean $-0,5 \mathrm{std}$ and $<$ mean $+0,5$ stdv), and $\mathrm{L}=(<$ mean - 0,5 stdv). However, the pod yield data was not included in the analysis of variance (ANOVA) as only single data or replicate was obtained. This data was not also used in the cluster analysis as the physical and chemical characteristics of peanut germplasm collection is of concern to obtain promising accessions as parents or crossed materials for breeding peanut varieties suited for food and industry application.

\section{RESULTS AND DISCUSSION}

\section{Physical characteristics}

Most of peanut genotypes (93\%) had rose seed coat color, while only one (MLGA 0416) and three genotypes (MLGA 0261, MLGA 0542, MLGA 0621) had red and variegated color, respectively. The variation of peanut seed coat colors is shown in Figure 1. Similar rose color was also noted for the majority $(93.3 \%)$ of 148 accessions of peanut local variety collected from Java, Bali, West and East Nusa Tenggara (Trustinah 2009) as well as for $91 \%$ of 200 peanut germplasm collected by Indonesian Centre for Agricultural Biotechnology and Genetic Resources Research and Development (ICABIOGRAD) in Bogor (Zulchi et al. 2016). The seed coat color would affect the final color of peanut products and subsequently the quality and consumer preference. The presence of tannin and catechol that belong to phenolic compounds is highly attributed to seed coat color (Ma et al. 2012). Deep seed coat color is less favored compared to light color as it may turn to dark during storage as a result of oxidation of such phenolic compounds (Nasar-Abas et al. 2008) and associate with bitter and astringent flavors (Drewnowski and GomezCarneros 2000). Therefore, most peanuts improved varieties had rose seed coat color and about $95 \%$ of peanut planting area is currently grown with rose coat color, suggesting the predominant market preference for this type of peanut (Kasno and Harnowo 2014). Changing the peanut seed coat color into brown or dark brown may also occur during processing with heat treatments, such as roasting, dry blanching and oven-drying due to reaction of sugars and amino acids existing in the seed coat (Maillard reaction) resulting in brown products, such as melanoidins (Nasar-Abas et al. 2008, Segev et al. 2012). This would give darker color toward the final peanut products, particularly for those having deep seed coat color.
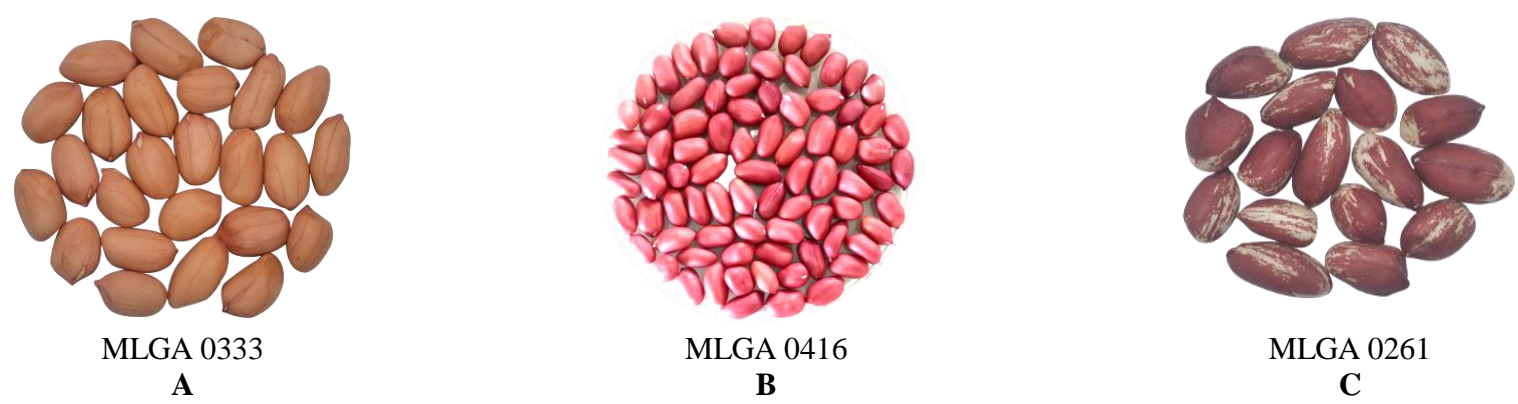

Figure 1. The seed coat color of selected peanut genotype: (A) rose, (B) red and (C) variegated 
Table 1. Physical and chemical characteristics and dried pod yield of sixty peanut genotypes

\begin{tabular}{|c|c|c|c|c|c|c|}
\hline Genotype & Origin & $\begin{array}{c}\text { 100-seed } \\
\text { weight }(\mathrm{g})\end{array}$ & $\begin{array}{c}\text { Ash } \\
(\% \text { dw }) \\
\end{array}$ & $\begin{array}{l}\text { Protein } \\
(\% \text { dw }) \\
\end{array}$ & $\begin{array}{c}\text { Fat } \\
(\% \text { dw })\end{array}$ & $\begin{array}{l}\text { Yield of dried } \\
\operatorname{pod}(\mathrm{t} / \mathrm{ha})\end{array}$ \\
\hline MLGA 0120 & ICRISAT, India & $52.1 \pm 0.1$ & $2.72 \pm 0.01$ & $28.57 \pm 0.31$ & $49.70 \pm 0.19$ & 3.60 \\
\hline MLGA 0122 & ICRISAT, India & $47.4 \pm 0.1$ & $2.58 \pm 0.00$ & $28.12 \pm 0.24$ & $48.45 \pm 0.30$ & 2.04 \\
\hline MLGA 0223 & ICRISAT, India & $63.0 \pm 0.3$ & $2.62 \pm 0.01$ & $29.11 \pm 0.25$ & $46.53 \pm 0.12$ & 3.36 \\
\hline MLGA 0225 & ICRISAT, India & $61.2 \pm 0.1$ & $2.71 \pm 0.01$ & $27.44 \pm 0.13$ & $50.12 \pm 0.25$ & 2.67 \\
\hline MLGA 0226 & ICRISAT, India & $53.4 \pm 0.2$ & $2.75 \pm 0.05$ & $28.84 \pm 0.00$ & $45.50 \pm 0.64$ & 3.62 \\
\hline MLGA 0260 & ICRISAT, India & $55.5 \pm 0.3$ & $2.86 \pm 0.05$ & $27.71 \pm 0.53$ & $46.76 \pm 0.39$ & 3.21 \\
\hline MLGA 0261 & ICRISAT, India & $57.8 \pm 0.2$ & $2.81 \pm 0.01$ & $27.86 \pm 1.42$ & $49.94 \pm 0.58$ & 2.99 \\
\hline MLGA 0294 & ICRISAT, India & $49.6 \pm 0.2$ & $2.68 \pm 0.02$ & $28.05 \pm 1.18$ & $47.16 \pm 0.15$ & 3.46 \\
\hline MLGA 0316 & ICRISAT, India & $46.5 \pm 0.2$ & $2.73 \pm 0.00$ & $26.83 \pm 0.57$ & $46.55 \pm 1.29$ & 3.39 \\
\hline MLGA 0333 & ICRISAT, India & $46.7 \pm 0.1$ & $2.95 \pm 0.01$ & $26.27 \pm 0.50$ & $50.29 \pm 0.28$ & 3.19 \\
\hline MLGA 0342 & ICRISAT, India & $35.2 \pm 0.3$ & $2.53 \pm 0.02$ & $27.57 \pm 1.61$ & $48.11 \pm 0.23$ & 2.29 \\
\hline MLGA 0356 & ICRISAT, India & $49.6 \pm 0.2$ & $2.78 \pm 0.00$ & $29.35 \pm 0.28$ & $44.89 \pm 0.01$ & 2.89 \\
\hline MLGA 0361 & ICRISAT, India & $55.4 \pm 0.2$ & $2.71 \pm 0.01$ & $28.81 \pm 0.95$ & $46.62 \pm 0.09$ & 4.17 \\
\hline MLGA 0365 & ICRISAT, India & $52.1 \pm 0.1$ & $2.79 \pm 0.02$ & $26.24 \pm 0.32$ & $46.56 \pm 0.13$ & 3.58 \\
\hline MLGA 0367 & ICRISAT, India & $47.2 \pm 0.2$ & $2.82 \pm 0.02$ & $27.61 \pm 0.26$ & $45.61 \pm 0.31$ & 3.06 \\
\hline MLGA 0368 & ICRISAT, India & $49.1 \pm 0.2$ & $2.80 \pm 0.01$ & $27.08 \pm 0.06$ & $47.87 \pm 0.22$ & 2.38 \\
\hline MLGA 0371 & ICRISAT, India & $44.6 \pm 0.2$ & $2.84 \pm 0.02$ & $26.20 \pm 1.18$ & $47.32 \pm 0.09$ & 2.49 \\
\hline MLGA 0379 & ICRISAT, India & $62.2 \pm 0.2$ & $2.68 \pm 0.03$ & $28.73 \pm 0.07$ & $47.82 \pm 0.00$ & 2.80 \\
\hline MLGA 0380 & ICRISAT, India & $44.1 \pm 0.3$ & $2.79 \pm 0.09$ & $27.89 \pm 0.65$ & $47.70 \pm 0.11$ & 2.74 \\
\hline MLGA 0387 & ICRISAT, India & $54.3 \pm 0.2$ & $2.66 \pm 0.02$ & $27.22 \pm 0.08$ & $47.92 \pm 0.24$ & 2.93 \\
\hline MLGA 0388 & ICRISAT, India & $66.8 \pm 0.2$ & $2.68 \pm 0.00$ & $28.88 \pm 0.18$ & $49.67 \pm 0.24$ & 2.82 \\
\hline MLGA 0409 & ICRISAT, India & $52.3 \pm 0.2$ & $2.98 \pm 0.15$ & $27.34 \pm 0.25$ & $47.11 \pm 1.58$ & 3.67 \\
\hline MLGA 0416 & ICRISAT, India & $51.5 \pm 0.2$ & $2.79 \pm 0.01$ & $26.01 \pm 0.46$ & $47.94 \pm 0.31$ & 2.67 \\
\hline MLGA 0425 & ICRISAT, India & $60.0 \pm 0.1$ & $2.76 \pm 0.06$ & $29.00 \pm 0.58$ & $47.62 \pm 0.17$ & 2.93 \\
\hline MLGA 0433 & ICRISAT, India & $58.8 \pm 0.3$ & $2.78 \pm 0.01$ & $28.56 \pm 0.54$ & $47.59 \pm 0.84$ & 3.01 \\
\hline MLGA 0444 & ICRISAT, India & $48.6 \pm 0.3$ & $2.72 \pm 0.05$ & $30.08 \pm 1.14$ & $47.75 \pm 0.94$ & 2.77 \\
\hline MLGA 0450 & ICRISAT, India & $54.9 \pm 0.2$ & $2.90 \pm 0.06$ & $27.70 \pm 0.73$ & $49.25 \pm 0.53$ & 3.77 \\
\hline MLGA 0488 & ICRISAT, India & $38.9 \pm 0.3$ & $2.80 \pm 0.02$ & $25.73 \pm 0.28$ & $48.13 \pm 0.41$ & 2.69 \\
\hline MLGA 0542 & ICRISAT, India & $52.3 \pm 0.2$ & $2.74 \pm 0.01$ & $25.25 \pm 0.59$ & $48.60 \pm 0.13$ & 3.73 \\
\hline MLGA 0621 & ICRISAT, India & $65.2 \pm 0.2$ & $2.74 \pm 0.03$ & $27.51 \pm 0.20$ & $51.23 \pm 0.35$ & 2.79 \\
\hline MLGA 0003 & Indonesia BL & $73.6 \pm 0.2$ & $2.61 \pm 0.01$ & $28.21 \pm 0.09$ & $47.78 \pm 0.06$ & 3.46 \\
\hline MLGA 0307 & Indonesia BL & $39.9 \pm 0.3$ & $2.86 \pm 0.02$ & $29.07 \pm 0.35$ & $45.30 \pm 0.49$ & 2.90 \\
\hline MLGA 0473 & Indonesia BL & $52.2 \pm 0.2$ & $2.64 \pm 0.01$ & $27.86 \pm 0.33$ & $46.46 \pm 0.28$ & 3.06 \\
\hline MLGA 0499 & Indonesia BL & $54.9 \pm 0.3$ & $2.63 \pm 0.00$ & $29.10 \pm 0.39$ & $44.55 \pm 1.84$ & 3.66 \\
\hline MLGA 0513 & Indonesia BL & $42.4 \pm 0.3$ & $2.72 \pm 0.01$ & $23.99 \pm 0.45$ & $46.90 \pm 0.07$ & 2.76 \\
\hline MLGA 0558 & Indonesia BL & $67.6 \pm 0.2$ & $2.61 \pm 0.01$ & $27.28 \pm 0.20$ & $47.29 \pm 0.46$ & 4.32 \\
\hline MLGA 0560 & Indonesia BL & $57.2 \pm 0.1$ & $2.67 \pm 0.02$ & $29.80 \pm 0.56$ & $45.68 \pm 0.51$ & 3.64 \\
\hline MLGA 0562 & Indonesia BL & $60.6 \pm 0.1$ & $2.65 \pm 0.01$ & $28.98 \pm 0.28$ & $45.85 \pm 0.93$ & 2.93 \\
\hline MLGA 0563 & Indonesia BL & $58.9 \pm 0.1$ & $2.67 \pm 0.00$ & $27.72 \pm 0.54$ & $45.95 \pm 1.13$ & 3.22 \\
\hline MLGA 0572 & Indonesia BL & $58.1 \pm 0.1$ & $2.64 \pm 0.02$ & $27.06 \pm 0.53$ & $46.60 \pm 0.01$ & 3.95 \\
\hline MLGA 0628 & Indonesia BL & $48.4 \pm 0.2$ & $2.67 \pm 0.01$ & $26.34 \pm 0.76$ & $47.83 \pm 0.69$ & 2.55 \\
\hline MLGA 0015 & Indonesia LV & $54.0 \pm 0.2$ & $2.68 \pm 0.01$ & $27.52 \pm 1.02$ & $46.41 \pm 0.03$ & 3.80 \\
\hline MLGA 0023 & Indonesia LV & $63.0 \pm 0.3$ & $2.57 \pm 0.00$ & $27.66 \pm 0.60$ & $46.98 \pm 0.28$ & 2.89 \\
\hline MLGA 0029 & Indonesia LV & $74.1 \pm 0.2$ & $2.67 \pm 0.05$ & $28.82 \pm 0.54$ & $47.96 \pm 1.22$ & 2.44 \\
\hline MLGA 0032 & Indonesia LV & $45.1 \pm 0.1$ & $2.71 \pm 0.02$ & $24.08 \pm 0.34$ & $48.23 \pm 0.44$ & 3.62 \\
\hline MLGA 0040 & Indonesia LV & $46.6 \pm 0.3$ & $2.70 \pm 0.01$ & $26.81 \pm 0.66$ & $47.13 \pm 0.20$ & 2.85 \\
\hline MLGA 0053 & Indonesia LV & $46.2 \pm 0.2$ & $2.85 \pm 0.02$ & $25.57 \pm 0.38$ & $47.42 \pm 0.51$ & 3.29 \\
\hline MLGA 0059 & Indonesia LV & $64.5 \pm 0.2$ & $2.74 \pm 0.01$ & $26.55 \pm 0.03$ & $50.96 \pm 0.33$ & 3.46 \\
\hline MLGA 0060 & Indonesia LV & $45.4 \pm 0.2$ & $2.84 \pm 0.00$ & $25.15 \pm 0.78$ & $47.88 \pm 1.18$ & 1.58 \\
\hline MLGA 0071 & Indonesia LV & $53.6 \pm 0.1$ & $2.64 \pm 0.00$ & $27.38 \pm 0.12$ & $48.33 \pm 1.05$ & 1.95 \\
\hline MLGA 0138 & Indonesia LV & $41.8 \pm 0.2$ & $2.64 \pm 0.02$ & $25.72 \pm 0.65$ & $46.53 \pm 0.11$ & 3.47 \\
\hline MLGA 0138 & Indonesia LV & $45.8 \pm 0.2$ & $2.55 \pm 0.01$ & $27.42 \pm 0.16$ & $48.80 \pm 0.21$ & 3.32 \\
\hline MLGA 0159 & Indonesia LV & $59.3 \pm 0.2$ & $2.65 \pm 0.04$ & $28.10 \pm 0.76$ & $46.92 \pm 0.37$ & 2.69 \\
\hline MLGA 0199 & Indonesia LV & $47.0 \pm 0.1$ & $2.66 \pm 0.00$ & $29.31 \pm 0.62$ & $46.92 \pm 0.01$ & 3.16 \\
\hline MLGA 0216 & Indonesia LV & $40.1 \pm 0.2$ & $2.72 \pm 0.00$ & $26.29 \pm 0.07$ & $49.21 \pm 0.64$ & 3.61 \\
\hline MLGA 0220 & Indonesia LV & $51.3 \pm 0.2$ & $2.80 \pm 0.02$ & $28.92 \pm 0.29$ & $46.71 \pm 0.00$ & 2.90 \\
\hline MLGA 0492 & Indonesia LV & $45.6 \pm 0.3$ & $2.80 \pm 0.05$ & $28.27 \pm 0.32$ & $46.70 \pm 0.18$ & 2.44 \\
\hline MLGA 0629 & Indonesia LV & $50.5 \pm 0.2$ & $2.76 \pm 0.00$ & $27.39 \pm 0.65$ & $45.90 \pm 0.43$ & 2.62 \\
\hline MLGA 0636 & Indonesia LV & $44.0 \pm 0.3$ & $2.78 \pm 0.01$ & $28.43 \pm 0.09$ & $47.65 \pm 0.27$ & 3.51 \\
\hline MLGA 0643 & Indonesia LV & $57.5 \pm 0.2$ & $2.74 \pm 0.01$ & $27.36 \pm 1.21$ & $46.27 \pm 0.16$ & 3.51 \\
\hline Minimum & - & $35.2 \pm 0.3$ & $2.53 \pm 0.02$ & $23.99 \pm 0.45$ & $44.89 \pm 0.01$ & 1.58 \\
\hline Maximum & - & $74.1 \pm 0.2$ & $2.98 \pm 0.15$ & $30.08 \pm 1.14$ & $51.23 \pm 0.35$ & 4.32 \\
\hline Mean \pm SD & - & $52.7 \pm 8.4$ & $2.73 \pm 0.02$ & $27.55 \pm 0.36$ & $47.49 \pm 0.41$ & $3.09 \pm 0.54$ \\
\hline
\end{tabular}

Note: dw: dry weight, SD: standard deviation, LV: local variety, BL: breeding line 
The 100-seed weight varied greatly from $35.2 \mathrm{~g}$ to 74.1 $\mathrm{g}$ with a mean of $52.7 \mathrm{~g}$ (Table 1). Twenty-one genotypes (35\%) belonged to large-seeded $(\geq 55 \mathrm{~g} / 100$ seeds) (Trustinah 2009), which mostly (19\%) had 100-seed weight between $55 \mathrm{~g}$ to $62.5 \mathrm{~g}$ (Figure 2). Meanwhile, three genotypes were small-seeded $(<40 \mathrm{~g} / 100$ seeds $)$ and the rest were medium with the majority $(26 \%)$ around $47.5 \mathrm{~g}$ to $52.5 \mathrm{~g}$ (Figure 2). About five genotypes had fairly large seed sizes with 100 -seed weight $\geq 65$ g, namely MLGA 0029, MLGA 0003, MLGA 0558, MLGA 0059 (local varieties), and MLGA 0388 (introduction) (Table 1), suggesting the potential genetic sources for large-seeded peanut selection. The seed sizes observed in present study were relatively larger than 34 Indonesian peanut varieties that had 100-seed weight ranging from $31 \mathrm{~g}$ to $65 \mathrm{~g}$ (Kasno and Harnowo 2014) and three genotypes of ICRISAT's germplasm, India (42,40-49.88 g) (Upadhyaya et al. 2012). Smaller number of large-seeded peanut $(30 \%)$ was also noted in 200 accessions of ICABIOGRAD GenBank (Zulchi et al. 2016). However, much larger values of 100seed weight (95.4-106.9 g) were reported for Turkey peanut varieties (Özcan 2010). Large and medium-seeded is tailored for boiled, deep-fried, and oven-roasted peanut, snacks and confectionery (Bishi et al. 2013), while smallseeded is favored for peanut sauce, snacks/bakery fillers, and flour coated peanuts.

Most genotypes (83\%) had two seeds per pod, which is highly demanded by oven-roasted peanut industry and would have higher selling price relative to those with three or four seeds per pod (Ginting et al. 2015). Upadhyaya et al. (2006) noted a positive correlation between 100-seed weight (seed size) with the pod yield for 21 peanut accessions grown in India, however, such finding was not obtained in this study $(r=0.19)$ that might be due to a wide range of seed sizes (Table 1 and Figure 2). Rahmianna et al. (2012) also revealed that seed weight per plant had more effects on the pod yield $(r=0.95)$ rather than seed size $(r=$ $0.73)$.

\section{Chemical characteristics}

The ash contents as the representative of minerals in peanut seed were significantly different between genotypes $(P<0.05$, data not shown), even though small range values were noted, c.a. $2.53 \%$ to $2.98 \%$ (dw) as listed in Table 1 , suggesting a genetic effect on ash content as all genotypes were grown in the same location and season. These values were also similar to that of Indonesian Local Ponorogo variety with ash content of $2.46 \%$ (Ginting et al. 2018), as well as with JL-24, an Indian variety $(2.58 \%)$ and four peanut cultivars originated from Ghana, c.a. 2.45-2.96\% (Ingale and Shrivastava 2011, Eshun et al. 2013). Özcan (2010) reported a slightly smaller range of ash content in Turkey's peanut genotypes, c.a. 1.61 to $2.36 \%$, but much higher in six and five peanut varieties grown in Nigeria and Bangladesh that ranged between $3.0-7.4 \%$ and $7.8-9.6 \%$, respectively (Musa et al. 2010, Chowdhory et al. 2015). Differences in peanut genotypes and growing environment may contribute to such differences in ash contents (PhanThien et al. 2010), particularly climate/season, temperature, soil structure, and fertility (Özcan 2010). K, P, Mg, Ca, Na, $\mathrm{Fe}, \mathrm{Cu}, \mathrm{Mn}$, and $\mathrm{Zn}$ are the main macro and micro minerals in peanut (Phan-Thien et al. 2010, Ingale and Shrivastava 2011, Settaluri et al. 2012). High ash content tends to give darker color to the products, particularly for those are prepared using heating below the complete ashing temperature $\left(500-600^{\circ} \mathrm{C}\right)$ (Kartika 2014).

The protein content varied between peanut genotypes $(P<0.05$, data not shown), ranging from $23.99 \%$ to $30.08 \%(\mathrm{dw})$ with a mean of $27.55 \%$ as presented in Table 1. About 17 genotypes (28.3\%) and 11 genotypes (18.3\%) contained protein $27.5-28 \%$ and $28.5-29 \%$, respectively as the major values observed among 60 genotypes (Figure 3). Peanut seed with protein content $>30 \%$ is classified as high, while it is medium for $25-30 \%$ and low for $<25 \%$ (Zulchi and Puad 2017). Based on such criteria, one genotype had high protein content, two genotypes were low and the rest of 57 genotypes were medium. These values were within the range of normal protein contents in peanut, c.a. $25-32 \%$ (Özcan 2010) as well as in Indonesian peanut varieties released from 2001 until 2016 which was as low as $18.4 \%$ in Tala 2 up to $32.8 \%$ in Takar 2 (ILETRI 2016). Similar findings were also noted for peanuts collected from Turkey (25.9-32.4\%), Nigeria (26.3-30.9\%), China (18.93$30.22 \%$ ), and 240 ICABIOGRAD GenBank (23.2-32.7\%), respectively (Atasie et al. 2009, Özcan 2010, Wang et al. 2011, Zulchi and Puad 2017). However, lower values $(17.18-25.08 \%)$ and $(15.77-27.60 \%)$ were previously published in 12 Indian accessions and 184 ICRISAT's germplasm, respectively (Upadhyaya et al. 2012, Mukri et al. 2014). Protein content of peanut is a quantitative trait that is considerably affected by genetic and environmental factors (Sarvamangala et al. 2011). MLGA 0444 genotype (introduction) with protein content $30.08 \%$ is promising to be a parent or genetic source for high protein peanut breeding purposes. Zulchi et al. (2017) also reported that there were only 13 out of 804 peanut accessions in ICABIOGRAD GenBank contained protein $>30 \%$. Peanut with high protein and oleic acid contents is preferred for ingredient of peanut food products (Upadhyaya et al. 2012; Janila et al. 2013).

Sixty peanut genotypes showed a wide variation in fat content $(P<0.05$, data not shown $)$ that ranged from $44.55 \%$ to $51.23 \%$ (dw) with a mean of $47.49 \%$ (Table 1 ). The major genotypes (65.3\%) had fat content around 46.0$48.5 \%$ (Figure 4), while Zulchi et al (2017) noted only 14 genotypes out of 804 accessions (1.7\%) in ICABIOGRAD GenBank contained fat $>45 \%$. All genotypes belonged to high-fat peanut $(>43 \%)$, thus no genotype had low $(<38 \%)$ or medium fat (38-43\%) as referred to Zulchi et al. (2017). Among the three origins of the genotypes studied (local, breeding line, and introduction), the introduction group gave a wide range of fat content, and three out of four genotypes having fat contents $>50 \%$ belonged to this group. Peanut normally had fat content $42-52 \%$ (Özcan 2010), which was in agreement with the values obtained in present study. A number of Indonesian released peanut varieties also had similar fat contents that ranging from $40.3 \%$ in Takar 2 up to $50 \%$ in Kancil and Sima (ILETRI 
2016). Four genotypes with fat content > 50\%, namely MLGA 0621, MLGA 0059, MLGA 0333, and MLGA 0225 are tailored for peanut oil extraction purposes as ingredients for edible oil, margarine, and shortening (Upadhyaya et al. 2012; Janila et al. 2013). Even though a small variation of fat content was observed in this study, such genotypes with considerably high-fat contents in our germplasm collections are potential to be used as genetic sources for breeding of high-fat peanuts. Efforts to improve the fat content and its genetic diversity in the germplasm collection can be also performed through introduction genotypes as the fat content may range from $31.7 \%$ to $57 \%$ (Yol et al. 2017) as well as wild Arachis species with fat content 45-55\% and 51.40-63.34\% (Upadhyaya et al. 2011; Huang et al. 2012).

Özcan (2010) and Upadhyaya et al. (2012) reported a slightly lower fat content in peanuts originated from Turkey and Indian germplasm, c.a. 32.7-45.4\% and 39.11-

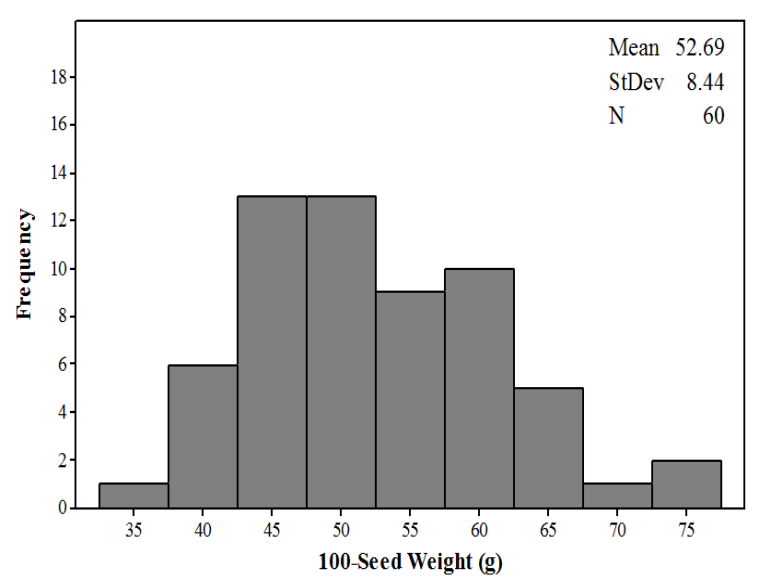

Figure 2. Distribution 100-seed weight of 60 peanut genotypes

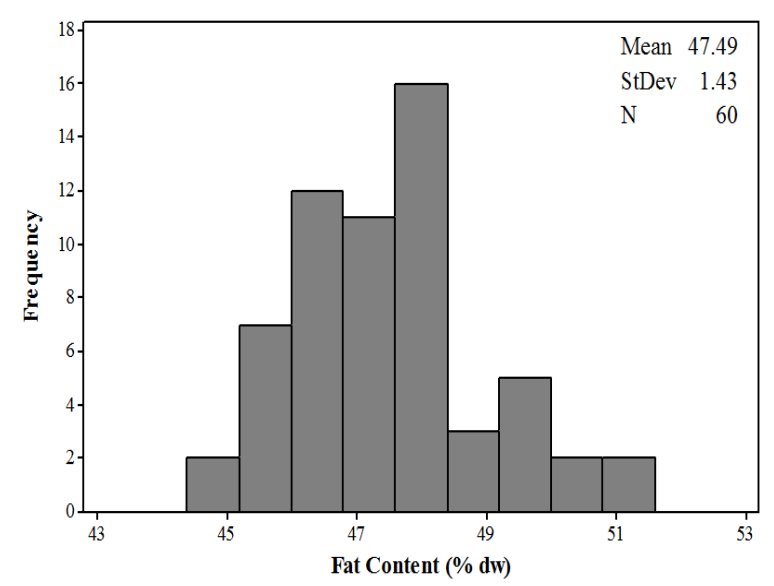

Figure 4. Distribution of fat content of 60 peanut genotypes
$47.41 \%$, respectively as well as in 45 peanut genotypes grown in Malang, c.a. 37.7-45.7\% (Trustinah and Kasno 2012) compared to present study. Meanwhile, they were approximately the same as those of 29 peanut genotypes grown in Nigeria, c.a. 47.0-50.1\% (Atasie et al. 2009) and slightly lower relative to 152 Chinese genotypes and 60 Indian Spanish germplasm, c.a. 37.42-55.69\% and 47.1$54.6 \%$, respectively (Wang et al. 2011, Bishi et al. 2013). This suggests that both genotype and growing conditions highly contribute to fat content of peanut (Sarvamangala et al. 2011). In addition to fat content, the profile of peanut fatty acids is also essential, particularly for edible oil uses. Peanut oil with higher proportion of oleic acid (C18: 1) than linoleic acid (C18: 2) is desirable to maintain the oil stability and extend the shelf life (Chamberlin et al. 2011) as it is less susceptible to oxidation degradation (rancidity). Nevertheless, analysis of fatty acid profile was not performed in this study.

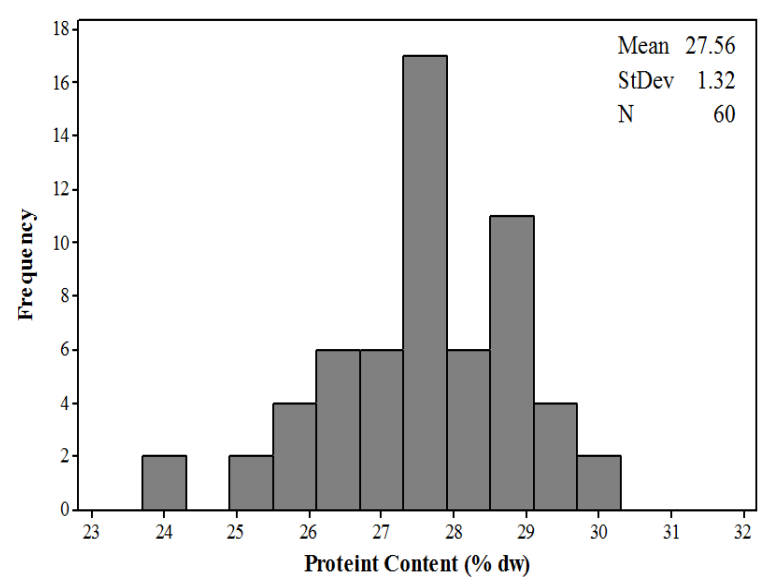

Figure 3. Distribution of protein content of 60 peanut genotypes

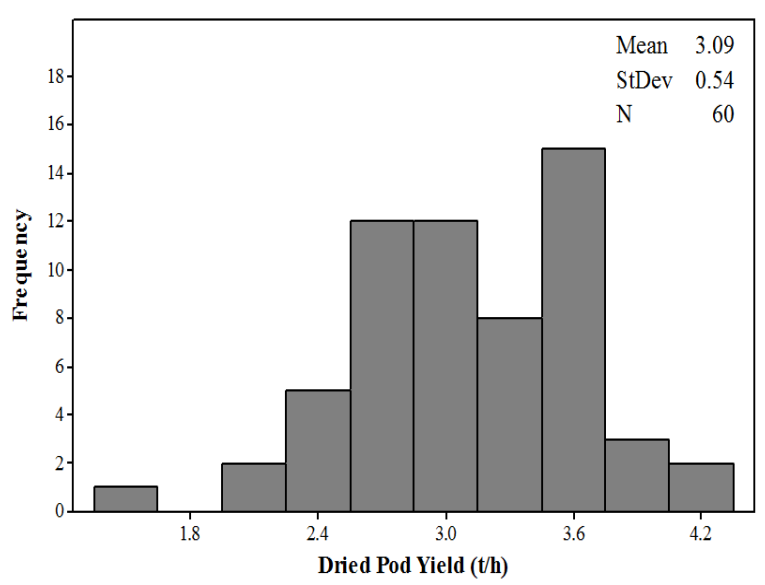

Figure 5. Distribution of pod yield of 60 peanut genotypes 
The protein content of 60 peanut genotypes showed a significant negative correlation with fat content $(r=-0.27)$ as seen in Figure 6. Sarvamangala et al. (2011) also found a similar result in 146 peanut inbred lines $(r=-0.294)$. However, Wang et al. (2011) revealed a non-significant correlation $(r=0.069)$ in 152 Chinese peanut accessions. Differences in genetic materials may cause such different findings. In terms of high protein and low-fat peanut, traits are concerned for ingredients of confectionery products (Wang et al. 2011), it seems possible to develop such variety considering the negative correlation of both traits. In particular, peanut with protein content $>25 \%$, fat content $\langle 45 \%, 100$-seed weight $>55 \mathrm{~g}$ and sugar content $>$ $11 \%$ is favored for confectionary uses in India (Janila et al. 2013). Since most of peanut genotypes in this study had relatively high-fat content $(\geq 45 \%)$ as well as major Indonesian improved varieties (ILETRI 2016), breeding for lowering the fat content in the future needs to be taken into account as peanut use in Indonesia is predominantly for food and food products, and only small amounts for edible oil (Ginting et al. 2018).

A great variation in dried pod yield was observed between genotypes that were as low as $1.58 \mathrm{t} / \mathrm{ha}$ in MLGA 0060 up to 4.32 t/ha in MLGA 0558 with a mean of 3.09 t/ha (Table 1). About $40 \%$ of the genotypes showed pod yields between 2.7 and 3.0 t/ha and $25 \%$ had pod yield of $3.6 \mathrm{t} /$ ha (Figure 5). These values were considerably higher than those of 34 Indonesian peanut improved varieties that ranged from $1.2 \mathrm{t} / \mathrm{ha}$ to $3.0 \mathrm{t} / \mathrm{ha}$ (Kasno and Harnowo 2014) and 45 genotypes grown in Malang, East Java, c.a 1.343.59 t/ha (Trustinah and Kasno 2012). Lower values of dried pod yield were also seen in five Indian accessions, c.a. 1.28-2.76 tha (Upadhyaya et al. 2012). This agronomic trait is remarkably dictated by environmental conditions in addition to genetic factors.

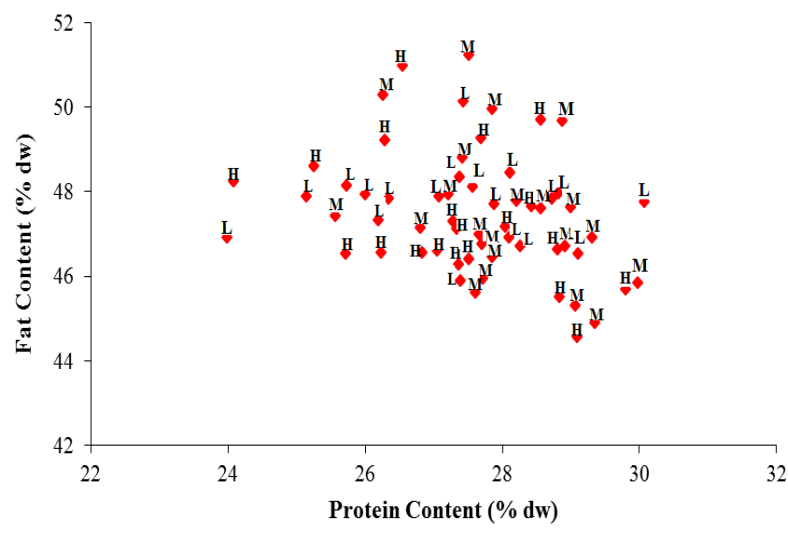

Figure 6. Scatter plot of protein and 100-seed weight for 60 peanut genotypes with label of pod yield. $\mathrm{H}$ : high pod yield, $\mathrm{M}$ : Medium, L: Low

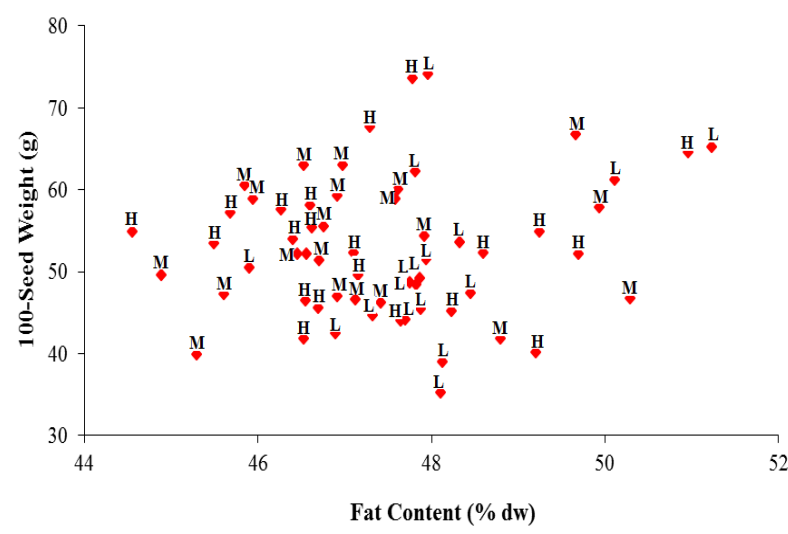

Figure 8. Scatter plot of fat and 100-seed weight for 60 peanut genotypes with label of pod yield. H: high pod yield, M: Medium, L: Low
Figure 7. Scatter plot of protein and fat contents for 60 peanut genotypes with label of pod yield. $\mathrm{H}$ : high pod yield, $\mathrm{M}$ : Medium, L: Low

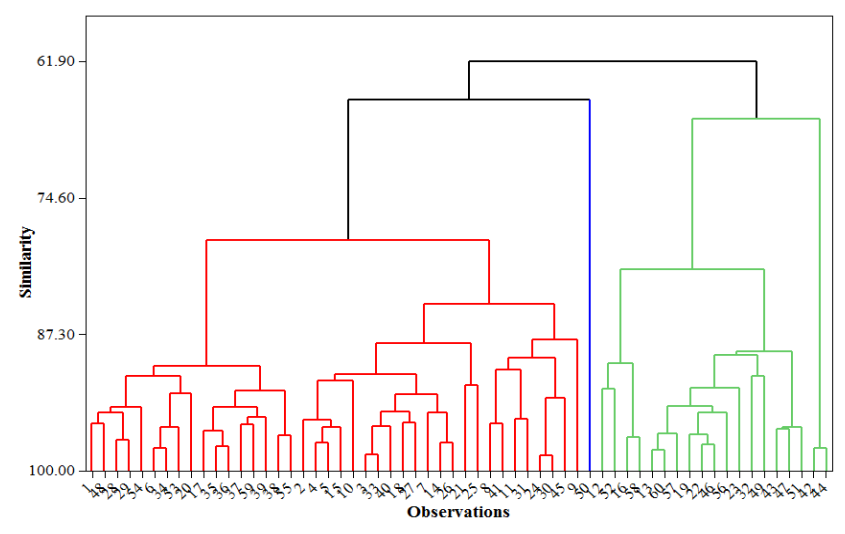

Figure 9. Cluster of 60 peanut genotypes based on their 100-seed weights, ash, protein and fat contents 
Table 2. Cluster of 60 peanut genotypes based on their 100-seed weights, ash, protein, and fat contents

\begin{tabular}{cccccc}
\hline $\begin{array}{c}\text { Number } \\
\text { of cluster }\end{array}$ & $\begin{array}{c}\text { Number } \\
\text { of } \\
\text { genotype }\end{array}$ & $\begin{array}{c}\text { 100-seed weight } \\
(\mathbf{g})\end{array}$ & $\begin{array}{c}\text { Ash }^{\text {a }} \\
(\mathbf{\%} \mathbf{~ d w})\end{array}$ & $\begin{array}{c}\text { Protein } \\
(\mathbf{\%} \mathbf{~ d w})\end{array}$ & $\begin{array}{c}\text { Fat }^{\text {a }} \\
(\mathbf{\%} \mathbf{~ d w})\end{array}$ \\
\hline I & 40 & $48.2(38.9-55.5)$ & $2.75(2.55-2.98)$ & $27.28(23.99-30.08)$ & $47.31(44.55-50.29)$ \\
II & 19 & $62.6(57.2-74.1)$ & $2.68(2.57-2.81)$ & $28.13(26.55-29.80)$ & $47.82(45.68-51.23)$ \\
III & 1 & 35.2 & 2.53 & 27.57 & 48.11 \\
\hline
\end{tabular}

Note: ${ }^{a}$ Mean (minimum-maximum)

Some genotypes in this study are likely promising to be used as genetic sources for high yield breeding purposes in a combination with physical and chemical characteristics. They were scattered for such characteristics with a label of high, medium, and low for dried pod yield as seen in Figures 6, 7, and 8. Two genotypes that had low protein contents but high-fat contents showed high pod yields, namely MLGA 0032 and MLGA 0542, while MLGA 0499 which also gave a high yield showed the lowest level of fat and medium of protein (Figure 6). In fact, no large-seeded genotype was observed to have high protein content as well as high pod yield. However, seven large-seeded genotypes with medium protein content (25-30\%) exhibited high pod yields (Figure 7), namely MLGA 0059, MLGA 0572, MLGA 0643, MLGA 0558, MLGA 0003, MLGA 0560, and MLGA 0361. In addition, eight genotypes that belonged to large-seeded peanuts with high-fat contents also showed high pod yields as illustrated in Figure 8, namely MLGA 0059, MLGA 0560, MLGA 0643, MLGA 0558, MLGA 0003, MLGA 0572, MLGA 0361, and MLGA 0316. Interestingly, the latter eight genotypes showed a high genetic variation of origin (Table 1). In particular, MLGA 0059 with characteristics of largeseeded, high-fat content, and high pod yield primarily collected from Bali (Local Bali variety) is promising to be released as a new variety.

Cluster analysis was done for physical and chemical characteristics, including 100-seed weight, ash, protein, and fat contents. Sixty peanut genotypes were grouped into three clusters based on such traits at $74 \%$ of similarity level that could cover all clusters (Figure 9). The major genotypes belonged to cluster I, while the smallest number was obtained for cluster III. The number of genotypes and criteria for each cluster was listed in Table 2. It is likely that the prominent difference in three clusters is seed size/100-seed weight, while ash, protein, and fat contents were only slightly different between clusters. This information would be expectedly useful for the breeder to select peanut germplasm as parental material or genetic resource for breeding of new varieties, particularly for those are superior in their physical characteristics and nutritional aspects as desired by food processors. Cluster II (19 genotypes) for instance is suitable for oil extraction purposes with respect to large seed size and high-fat content and the defatted seeds can be further used as ingredients for low-fat peanut snacks and peanut flour (Yulifianti et al. 2015).

In conclusion, the physical characteristics of most peanut genotypes studied (seed size, seed coat colors, and number of seed per pod) were likely tailored for peanut industry preferences. Genotypes with low protein and highfat contents were also observed, however no genotype with low fat and high protein existed. Selected promising genotypes with a favored combination of seed size and protein content as well as seed size with fat content which had high pod yield were available from this germplasm collection that can be directly used for breeding new varieties of peanut as supportive traits for their other superior agronomic characters.

\section{ACKNOWLEDGEMENTS}

We would like to thank the Indonesian Ministry of Agriculture through The Agency for Agricultural Research and Development (AARD) for financial and research facility support for this study as well as Dr. Heru Kuswantoro, Lina Kusumawati, Sunoto, and Priskilla Puji Larasati for their scientific and technical assistance.

\section{REFERENCES}

AOAC. 2016. Microchemical determination of nitrogen using micro Kjeldahl method (12.1.07). In: Latimer GWJr (ed). Official Methods of Analysis of AOAC International. 20 $0^{\text {th }}$ ed. AOAC International. Rockville, Maryland, USA.

Arya SS, Salve AR, Chauhan S. 2016. Peanuts as functional food: A review. J Food Sci Technol 53: 31-41.

Atasie VN, Akinhanmi TF, Ojiodu CC. 2009. Proximate analysis and physicochemical properties of groundnut (Arachis hypogaea L). Pakistan J Nutri 8: 194-197.

Bishi SK, Kumar L, Dagla MC, Mahatma MK, Rathnakumar AL, Lalwani HB, Misra JB. 2013. Characterization of Spanish peanut germplasm (Arachis hypogaea L.) for sugar profiling and oil quality. Industrial Crops Products 51: 46-50.

Chamberlin KD, Melouk HA, Madden R, Dillwith JW, Bannore Y, El Rassi Z, Payton M. 2011. Determining the oleic/linoleic acid ratio in a single peanut seed: A comparison of two methods. Peanut Sci 38: 7884.

Chowdhury FN, Hossain D, Hosen M,. Rahman S. 2015. Comparative study on chemical composition of five varieties of groundnut (Arachis hypogaea). World J Agric Sci 11: 247-254.

Dean LL, Hendrix KW, Holbrook CC, Sanders TH. 2009. Content of some nutrients in the core of the peanut germplasm collection. Peanut Sci 36: 104-120.

Drewnowski A, Gomez-Carneros C. 2000. Bitter taste, phytonutrients, and the consumer: A review. Am J Clin Nutr 72: 1424-35.

Eshun G, Amankwah EA, Barimah J. 2013. Nutrients content and lipid characterization of seed pastes of four selected peanut (Arachis hypogaea) varieties from Ghana. Afric J Food Sci 7: 375-381.

Ginting E, Rahmianna AA, Yusnawan E. 2018. Aflatoxin and nutrient contents of peanut collected from local market and their processed 
foods. IOP Conf Series: Earth Environ Sci 102: 012031. DOI: 10.1088/1755-1315/102/1/012031

Ginting E, Rahmianna AA. 2015. Infection of Aspergillus flavus and physical quality of peanuts collected from farmers, local markets, and processors. Proc Food Sci 3: 280-288.

Ginting E, Yulifianti R, Utomo JS. 2015. Peanut quality standard. In: Kasno A, Rahmianna AA, Mejaya IMJ, Harnowo D, Purnomo S (eds). Peanut. Indonesian Legumes and Tuber Crops Research Institute. Malang. [Indonesian]

Huang L, Jiang H, Ren X, Chen Y, Xiao Y, Zhao X, Tang M, Huang J, Upadhyaya HD, Liao B. 2012. Abundant microsatellite diversity and oil content in wild Arachis species. PLoS ONE 7 (11): e50002. DOI: 10.1371/journal.pone.0050002.

Hou M, Mu G, Zhang Y, Cui S, Yang X, Liu L. 2017. Evaluation of total flavonoid content and analysis of related EST-SSR in Chinese peanut germplasm. Crop Breed Appl Biotechnol 17: 221-227.

ILETRI. 2016. Description of varieties of legumes and tubers. Indonesian Legume and Tuber Crops Research Institute, Malang. [Indonesian]

Indonesian National Council for Standardization. 1992. Testing procedure for food and drinks (SNI 01-2891-1992). Jakarta. [Indonesian]

Ingale S, Shrivastava SK. 2011. Nutritional study of new variety of groundnut (Arachis hypogaea L.) JL-24 seeds. Afr J Food Sci 5: 490498.

Janila P, Nigam SN, Pandey MK, Nagesh P, Varshney RK. 2013. Groundnut improvement: Use of genetic and genomic tools. Fron Plant Sci 4: 1-17.

Jibrin MS, Habu SH, Echekwu CA, Abdullahi US, Usman IS. 2016 Phenotypic and genotypic variance and heritability estimates for oil content and other agronomic traits in groundnut (Arachis hypogaea L.). Int J Sci Res Eng Stud 3: 29-32.

Kabbia MK, Akromah R, Asibuo JW, Conteh AR, Kamara EG. 2017. Inheritance of seed quality traits in groundnut (Arachis hypogaea L.). Int J Dev Sustain 6: 526-544

Kartika EY. 2014. Determination of moisture and ash contents in biscuits. J Kimia Anal 2: 1-10. [Indonesian]

Kasno A, Harnowo D. 2014. Characteristics of improved peanut varieties and their adoption by farmers. Iptek Tan Pangan 9: 13-23. [Indonesian]

Ma Y, Kerr WL, Cavender GA, Swanson, RB, Hargrove JL, Pegg RB 2012. Effect of peanut skin incorporation on the color, texture and total phenolics content of peanut butter. J Food Proc Eng 36: 316-328

Mukri G, Nadaf HL, Gowda MVC, Bhat RS, Upadhyaya HD. 2014 Genetic diversity analysis based on nutritional, oil quality and yield component traits in mini core collection of groundnut (Arachis hypogaea L.). Karnataka J Agric Sci 27: 219-221.

Musa AK, Kalejaiye DM, Ismaila LE, Oyerinde AA. 2010. Proximate composition of selected groundnut varieties and their susceptibility to Trogoderma granarium Everts attack. J Stored Prod Postharvest Res 1: 13-17.

Nasar-Abbas SM, Plummer JA, Siddique KHM, White PF, Harris D, Dods K. 2008. Nitrogen retards and oxygen accelerates colour darkening in faba bean (Vicia faba L.) during storage. Postharvest Biol Technol 47: 113-118.

Noubissié TJB, Njintang NY, Dolinassou S. 2012. Heritability studies of protein and oil contents in groundnut (Arachis hypogaea L.) genotypes. Int J Innovations Biol Chem Sci 2: 162-171.

Özcan MM. 2010. Some nutritional characteristics of kernel and oil of peanut (Arachis hypogaea L.). J Oleo Sci 59: 1-5.

Phan-Thien KY, Wright GC, Lee NA. 2010. Genotype-by-environment interaction affects the essential mineral composition of peanu (Arachis hypogaea L.) kernels. J Agri Food Chem 58: 9204-9213.
Rahmianna AA, Taufiq A, Yusnawan E. 2012. Yield and quality of groundnut grown on various water availabilities and dolomite applications. J Penel Pert Tan Pangan 31 (1): 46-52. [Indonesian]

Respati E, Hasanah L, Wahyuningsih S, Sehusman, Manurung M. 2014. In: Sabarella (ed). III. Peanut. Bul Kon Pangan 5: 9-19. [Indonesian]

Sarvamangala C, Gowda MVC, Varshney RK. 2011. Identification of quantitative trait loci for protein content, oil content and oil quality for groundnut (Arachis hypogaea L.). Field Crops Res 122: 49-59.

Sebei K, Gnouma A, Herchi W, Sakouhi F, Boukhchina S. 2013. Lipids, proteins, phenolic composition, antioxidant and antibacterial activities of seeds of peanuts (Arachis hypogaea L.) cultivated in Tunisia. Biol Res 46: 257-263.

Segev A, Badani H, Galili L, Hovav R, Kapulnik Y, Shomer H. 2012. Effects of baking, roasting and frying on total polyphenols and antioxidant activity in colored chickpea seeds. Food Nutr Sci 3: 369376.

Settaluri VS, Kandala CVK, Puppala N, Sundaram J. 2012. Peanuts and their nutritional aspects: A review. Food Nutr Sci 3: 1644-.1650.

Statistics Indonesia. 2015. Peanut production according to province 19932015. www.bps.go.id/dynamictable/2015/09/09/874/produksi-kacangtanah-menurut-provinsi-ton-1993-2015.html [Indonesian]

Toomer OT. 2018. Nutritional chemistry of the peanut (Arachis hypogaea). Critic Rev Food Sci Nutr 58: 3042-3053.

Trustinah, Kasno A. 2012. Characterization of fatty acid composition in grains of groundnut genotypes. J Penel Pert Tan Pangan 31: 145-151. [Indonesian]

Trustinah. 2009. Groundnut germplasm: Diversity and potential for improving the newly progressive characters. Bul Pal 18: 58-65. [Indonesian]

Upadhyaya HD, Mukri G, Nadaf HL, Singh S. 2012. Variability and stability analysis for nutritional traits in the mini core collection of peanut. Crop Sci 52: 168-178.

Upadhyaya HD, Dwiveid SL, Nadaf HL, Singh S. 2011. Phenotypic diversity and identification of wild Arachis accessions with useful agronomic and nutritional traits. Euphytica 182: 103-115.

Upadhyaya HD, Reddy LJ, Gowda CLL, Singh S. 2006. Identification of diverse groundnut germplasm: Sources of early maturity in a core collection. Field Crops Res 97: 261-271.

Wang CT, Tang YY, Wang XZ, Chen DX, Cui FG, Chi YC, Zhang JC, Yu SL. 2011. Evaluation of groundnut genotypes from China for quality traits. J SAT Agri Res 9: 1-5.

Yol E, Ustun R, Golukcu M, Uzun B. 2017. Oil content, oil yield and fatty acid profile of groundnut germplasm in Mediterranea climates. J Am Oil Chem Soc 94: 787-804.

Yulifianti R, Santosa BAS, Widowati S. 2015. Processing technology of peanut products. In: Kasno A, Rahmianna AA, Mejaya IMJ, Harnowo D, Purnomo S (eds). Peanut. Indonesian Legumes and Tuber Crops Research Institute. Malang. [Indonesian]

Zulchi T, Afza H, Puad H. 2017. Groundnut germplasm collection in GenBank of ICABIOGRAD. In: Rahmianna AA, Harnowo D, Sholihin, Nugrahaeni N, Taufiq A, Suharsono, Yusnawan E, Ginting E, Rozi F, Hermanto (eds). Proceeding of The Seminar on Legumes and Tuber Crops Research. 2016. Center for Research and Development of Food Crops, Bogor. [Indonesian]

Zulchi T, Kurniawan H, Afza H, Puad H, Agus M, Nurul A. 2016. Germplasm diversity of groundnut based on the character of morphology, yield and oil content. J Pend Biol Indon 2: 133-146. [Indonesian]

Zulchi T, Puad H. 2017. Diversity of morphology and protein content of groundnut (Arachis hypogaea L.). Bul Plasma Nutfah 23: 91-100. [Indonesian] 